\title{
Governing the Lebanese health system: strengthening the national response to the burden of Syrian refugees
}

Alessio Santoro ${ }^{7}$ and Martin McKee ${ }^{2}$

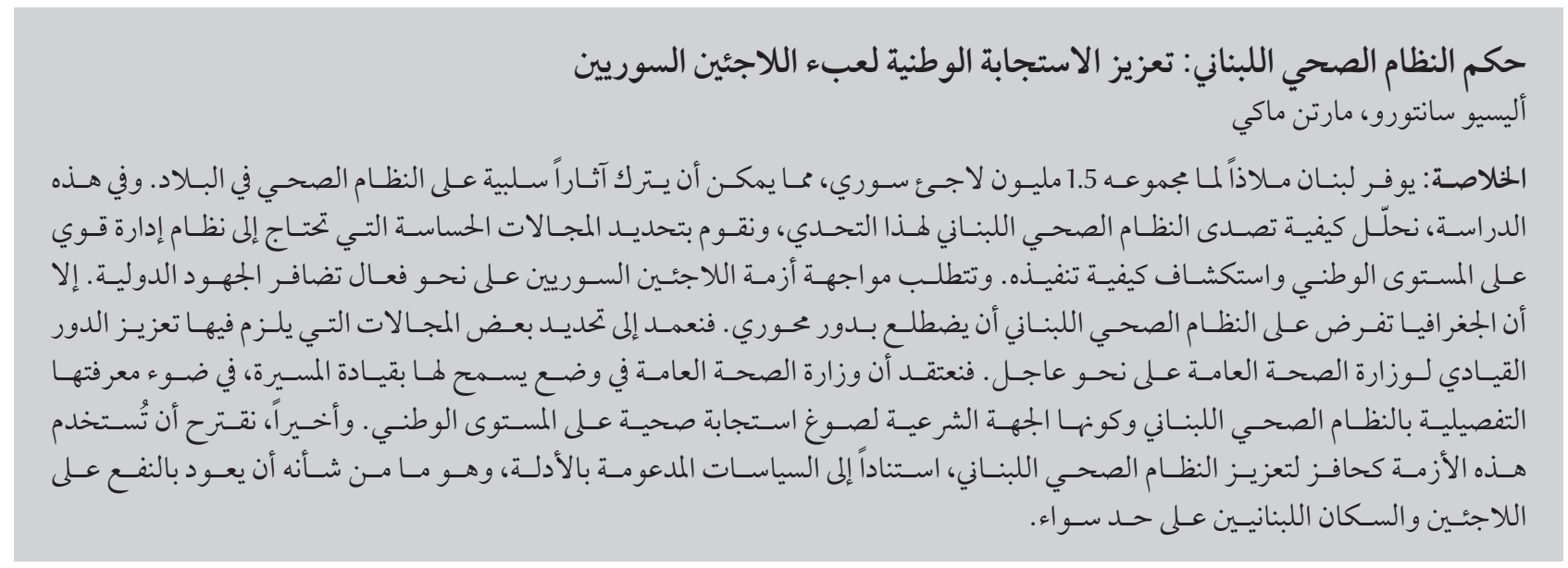

ABSTRACT Lebanon is providing sanctuary to an estimated 1.5 million Syrian refugees, with potential consequences for its health system. Here, we analyse how it has responded to this challenge, identify sensitive areas where a strong national governance system is needed and explore how it might be implemented. An effective response to the Syrian refugee crisis requires concerted international action. Nonetheless, geography dictates that the Lebanese health system must play a central role. We identify some areas where a strengthened stewardship role of the Ministry of Public Health is urgently required. We argue that the Ministry is well placed to take a lead, with its detailed knowledge of the Lebanese health system and its legitimacy to formulate a national health response. Finally, we suggest that this crisis could be a catalyst for the strengthening of the Lebanese health system, based on evidence-informed policies that would benefit refugees and the Lebanese population alike.

Gouvernance du système de santé libanais : renforcer la réponse nationale pour faire face au fardeau des réfugiés syriens

RÉSUMÉ Le Liban offre l'asile à 1,5 million de réfugiés syriens, selon les estimations, ce qui implique de potentielles conséquences sur le système de santé du pays. Dans la présente étude, nous analysons la façon dont le pays répond à ce défi, identifions les domaines sensibles dans lesquels un système de gouvernance national fort est requis, et réfléchissons aux moyens de le mettre en œuvre. Pour une réponse efficace à la crise des réfugiés syriens, une action internationale concertée est nécessaire. Néanmoins, la géographie impose au système de santé libanais de jouer un rôle central. Nous avons identifié les domaines où un renforcement du rôle de direction du ministère de la Santé publique est requis de toute urgence. Nous affirmons que le ministère de la Santé publique est bien placé pour assumer un rôle de direction, du fait de sa connaissance approfondie du système de santé libanais et de sa légitimité à mettre au point des interventions sanitaires à l'échelle nationale. Enfin, nous suggérons que cette crise peut être un catalyseur pour le renforcement du système de santé libanais, sur la base de politiques reposant sur des données factuelles qui pourraient bénéficier aux réfugiés ainsi qu'à la population libanaise.

'Institute of Hygiene, Catholic University of Sacred Heart, Rome, Italy (Correspondence to: A. Santoro: alessio.santoro@lshtm.ac.uk); ${ }^{2}$ Faculty of Public Health and Policy, European Centre on Health of Societies in Transition, London School of Hygiene and Tropical Medicine, London, United Kingdom.

Received: 18/05/15; accepted: 3/11/16 


\section{Introduction}

The Syrian conflict has caused an enormous number of refugees to seek sanctuary in neighbouring countries (1). This massive displacement of men, women and children has largely been absorbed by three countries: Lebanon, Jordan and Turkey, placing huge strain on their national health systems (2). Lebanon is a small country that hosts the largest density of refugees per capita in the world, and took informal steps to limit new arrivals in October 2014 (3). However, an estimated 1.5 million refugees have crossed the borders since the beginning of the conflict (1), placing severe pressure on the existing health system (4). The United Nations High Commission for Refugees (UNHCR) has called for the integration of refugees into the health system of the host country (5). Yet, such integration requires that the host country has strong mechanisms of governance in place. Here, we examine the Lebanese experience, with a focus on health system governance, and suggest measures that could benefit both the Lebanese health system and the refugees.

\section{An analytical framework}

The World Health Organization (WHO) (Figure 1) health systems framework defines governance as the key pillar, or building block, to ensure optimal delivery of services, effective design of financing mechanisms, efficient allocation of health workforce, appropriate development of an inclusive health information system, and eventually, adoption of adequate drugs procurement policies (6).

\section{The Lebanese health system}

Historically, the Lebanese health system has been highly fragmented (7). It relies heavily on regressive private funding, with widespread user fees. Public health services are mainly delivered through primary healthcare centres, run by nongovernmental organizations (NGOs) under contract. Secondary and tertiary care is mostly provided by the private sector (7). Within this context, the need for a strengthened MoPH was already acknowledged and led to the adoption of the "Ministry Action Plan 2003-2006”, aimed at strengthening its regulative capacity, providing universal access for basic health needs, and improving financial coverage for health services (7).

\section{Governance during the crisis: an assessment}

Any health system would have been challenged to respond to such a humanitarian crisis, with a 30\% increase in population in $<4$ years $(8)$. The health response is currently being jointly led by the MoPH, WHO and UNHCR (9). However, as the organ of national government, the MoPH must provide leadership (9). This view was reaffirmed at a policy dialogue held at the Gefinor Rotana Hotel in Beirut on 4th June 2014 that highlighted the need to strengthen the stewardship function of governmental departments (9).

The MoPHhasscaledupits commitments to respond to the health needs of the growing number of refugees, by increasing the capacity of primary healthcare centres, launching immunization campaigns, and ensuring that Syrian refugees are covered for emergency care (9). Its unique understanding of the Lebanese context makes the MoPH the most appropriate institution to govern the health response. The Ministry possesses a thorough knowledge of the Lebanese health system and its building blocks, including the distribution of facilities, information systems, and financial and human resources. Thus, its institutional legitimacy should place the $\mathrm{MoPH}$ in the forefront of the design and implementation of a renewed $\mathrm{Na}$ tional Health Response Plan. However, this has not yet been adopted (9).

A national plan offers several opportunities. First, it offers the possibility of matching existing assets efficiently to the needs of refugees; something that is particularly important in the absence of dedicated camps for Syrian refugees (10). There may have been good political reasons for not establishing refugee camps, although they would have made it easier to focus the health response within those settings, allowing a gradual integration of refugees within the Lebanese health system. Second, a national plan could facilitate the definition of a basic package of essential health services for Syrian refugees and the Lebanese people, which would allow the provision of services for refugees to be aligned with the health benefits provided for the host population (9). Third, by specifying precise roles and responsibilities for all the key actors, a national health plan could advance the long-advocated move to Lebanese ownership of the health system (9), allowing the MoPH to orchestrate the myriad of national and international actors involved while taking full advantage of the ability of the UN agencies in capacity building (11).

\section{Implications for health system building blocks}

The beneficial effects of strengthened governance led by the MoPH could have positive implications for the whole health system, which is severely overstretched by the rapidly increased demand for healthcare (4). Turning first to service delivery, in 2013, less than half of all refugees in need of care obtained it and, of those, $>50 \%$ did so privately (12). The health system could not meet the antenatal healthcare needs of Syrian women (13) and access to services for noncommunicable diseases was impeded by high costs of care (8). 
Financial barriers, many due to delays in registration with the UNHCR (the only means they had to obtain financial support for healthcare), led many refugees to make desperate attempt to return to the Syrian Arab Republic to seek treatment (8). The gap in the provision of health assistance is exacerbated by the fact that most Syrian refugees are living in locations where $67 \%$ of the host population is already living below the poverty line (14). Weaknesses in the information system restrict the ability of the authorities to ascertain the health needs of the Syrian refugees. Drug supplies are rapidly depleted and increased demand undermines the capacity of health workers to provide high-quality services (15). The MoPH also provides a mechanism to ensure accountability and to facilitate cross-government coordination.

\section{Experiences from other countries}

Previous experience from other countries suggests that there is huge scope for a strengthened national health response, with strong leadership by the MoPH. First, a particularly valuable lesson comes from Jordan; a country with a public healthcare system in which the
Ministry of Health took the lead and worked with international organizations to implement a response that sought to provide full access to preventative and curative services by refugees (16). The result was the adoption of the Jordan Response Plan 2015 for the Syrian crisis (17). This sought to strengthen the national health system and to enable it to respond better to the Syrian crisis, by mobilizing additional human and financial resources, strengthening data collection systems, and redesigning drug procurement policies (17).

Second, the Lebanese Government has the legitimacy to formulate a national health response, which can take account of both the needs of the refugee population and the available resources and assets. In Afghanistan, the MoPH assumed leadership of the health system after removal of the Taliban Regime in 2001. The system it inherited was highly fragmented and, recognizing its initially limited capacity, the MoPH stepped back from the direct provision of services, defined a basic package of health services, and contracted the healthcare delivery function to NGOs. This, in turn, optimized the contribution of international donors, who directly funded such contracts (18). Additionally, the national data collection mechanisms were strengthened by ensuring that
NGOs directly provided health data to the government's Health Management Information System. Furthermore, the involvement of a third party consortium - including Johns Hopkins University - in the evaluation of the performance of the NGOs, increased the potential to ensure delivery of high-quality services (18).

Third, Lebanon itself offers compelling evidence of what can be done to implement a data-driven package of basic health services, with alignment of donors' efforts within a National Health Plan that directs resources to where they are most needed. In 1992, following the Lebanese Civil War, a weak MoPH was able to develop a health sector strategy that emphasized its governance and stewardship roles (19). The MoPH strengthened its managerial and administrative capacity and developed a comprehensive package of curative and preventive services at all primary healthcare facilities. The lessons learnt highlighting the need for the MoPH to be the central player in a pluralistic system (19).

\section{The way forward}

The scale of the challenges facing the Lebanese health system is

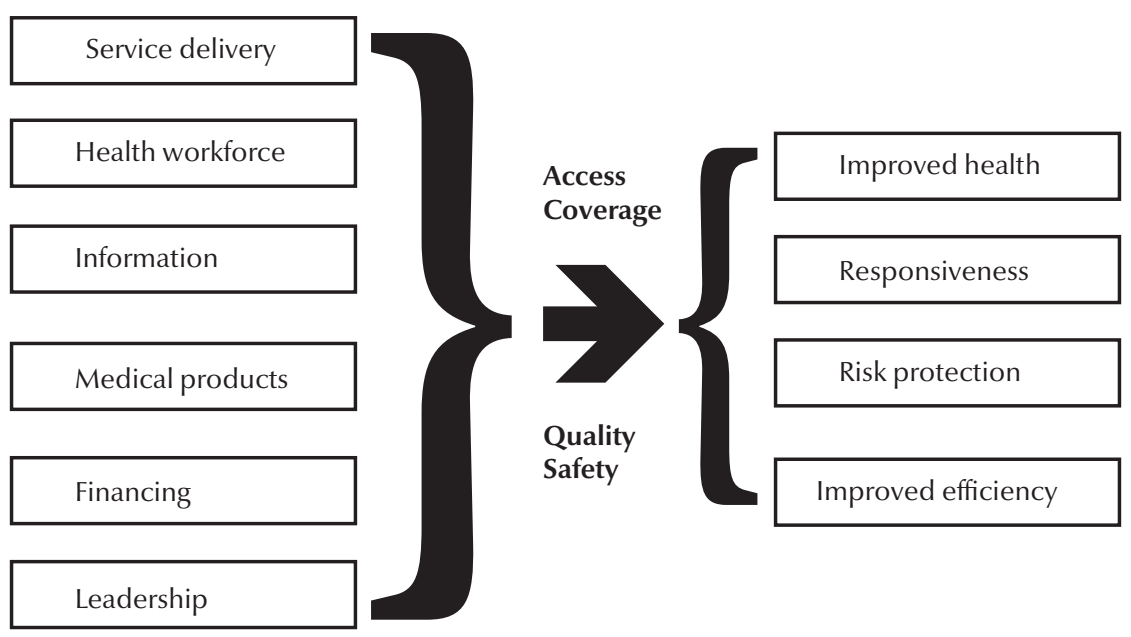

Figure 1 WHO Health System Framework (2007). 
enormous, and with no end in sight to the Syrian crisis, it is likely to get worse. Already, the UN Special Envoy to Syria, Staffan De Mistura, has said that the Syrian conflict has led to the largest humanitarian crisis since the Second World War (20). If the consequences in neighbouring countries are to be tackled effectively, there is a need to scale up the international response. The challenges brought by the Syrian refugees crisis should encourage the MoPH to take a lead, develop a national plan that will clarify roles and responsibilities of national and international actors and define basic packages for essential services that can provide a basis for harmonization of service provision. This should build upon the WHO's health system pillars. Despite the many challenges, this offers a means to begin the process of integrating the care of refugees within the Lebanese health system, with the definition of basic packages providing access to healthcare to refugees and host populations. The resulting strengthened Lebanese health system could bring benefits to the entire population.

Funding: None.

Competing interests: None declared.

\section{References}

1. Coutts A, Fouad FM. Response to Syria's health crisis-poor and uncoordinated. Lancet. 2013 Jun 29;381(9885):2242-3. PMID:23819155

2. 3RP Regional Refugee and Resilience Plan 2015-2016 in Response to the Syrian Crisis. 2015 Annual Report (data.unhcr. org/syrianrefugees/download.php?id=11002, accessed 26 April 2017).

3. Syrian refugeesseekinghelp.Lancet.2015Jan17;385(9964):202. PMID:25706695

4. Refaat MM, Mohanna K. Syrian refugees in Lebanon: facts and solutions. Lancet. 2013 Aug 31;382(9894):763-4. PMID:23870816

5. Zarocostas J. Integrate health services for refugees into national healthcare, says UN report. BMJ. 2011 Aug 19;343:d5244. PMID:21856764

6. Everybody's business. Strengthening health systems to improve health outcomes. WHO's framework for action. Geneva: World Health Organization; 2007 (http://www.who.int/ healthsystems/strategy/everybodys_business.pdf, accessed 21 March 2017).

7. Health System Profile Lebanon. Cairo: World Health Organization. Regional Office for the Eastern Mediterranean; 2006 (http://apps.who.int/medicinedocs/documents/s17301e/ s17301e.pdf, accessed 21 March 2017).

8. Lebanon: agonizing choices: Syrian refugees in need of health care in Lebanon. London: Amnesty International; 2014 (https://www.amnesty.org/en/documents/MDE18/001/2014/ en/, accessed 21 March 2017).

9. Hammoud R, El-Jardali F. K2P dialogue summary: promoting access to essential health care services for Syrian refugees in Lebanon. Beirut: American University of Beirut; 2014 (https:// www.aub.edu.lb/k2p/products/Documents/Policy\%20Dialogue\%20Summary_\%20Syrian\%20Refugees.pdf, accessed 21 March 2017).

10. American University in Beirut Knowledge to Policy. (K2P). Promoting access to essential health care services for Syrian refugees in Lebanon. Beirut, Lebanon: American University in Beirut, Knowledge to Policy (K2P)2014.

11. Salama P, Spiegel P, Talley L, Waldman R. Lessons learned from complex emergencies over past decade. Lancet. 2004 Nov 13-19;364(9447):1801-13. PMID:15541455
12. Rapid needs assesment: Haret Hreik. Amel Association International; 2013 (https://data.unhcr.org/syrianrefugees/download. php?id=2693, accessed 21 March 2017).

13. Benage M, Greenough PG, Vinck P, Omeira N, Pham P. An assessment of antenatal care among Syrian refugees in Lebanon. Confl Health. 2015;9:8. PMID:25741381

14. Improving health care services in Lebanon in the context of the Syrian crisis: the EU/IfS programme. Cairo: World Health Organization. Regional Office for the Eastern Mediterranean; 2017 (http://www.emro.who.int/lbn/lebanon-news/improving-health-care-services-in-lebanon-in-the-context-of-thesyrian-crisis.html, accessed 21 March 2017).

15. Lebanon: economic and social impact assessment of the Syrian conflict. Washington: World Bank; 2013 (https://openknowledge.worldbank.org/handle/10986/16790, accessed 21 March 2017).

16. His E, Murshidi MM, Hijjawi MQ, Jeriesat S, Eltom A. Syrian refugees and Jordan's health sector. Lancet. 2013 Jul 20;382(9888):206-7. PMID:23830357

17. Jordan Responce Plan 2015 for the Syria Crisis, final draft. Hashemite Kingdom of Jordan. Ministry of Planning and International Cooperation; 2014 (http://www.jo.undp.org/content/ dam/jordan/docs/Publications/JRP+Final+Draft+2014.12.17. pdf, accessed 21 March 2017).

18. Balabanova D, Oliveira-Cruz V, Hanson K. Health sector governance and implications for the private sector. New York: Rockefeller Foundation; 2008 (Technical partner paper 9; http://www.resultsfordevelopment.org/sites/resultsfordevelopment.org/files/resources/Health\%20Sector\%20 Governance\%20and\%20Implications\%20for\%20the\%20Private\%20Sector.pdf, accessed 21 March 2017).

19. Kronfol NM. Rebuilding of the Lebanese health care system: health sector reforms. East Mediterr Health J. 2006 MayJul;12(3-4):459-73. PMID:17037717

20. UN News Centre. UN envoy says Syria set back 40 years by war, calls for renewed push towards solution (http:// www.un.org/apps/news/story.asp?NewsID=49806\#.WNErrLSzD0c, accessed 21 March 2017). 